\title{
On Fixing Blowing Sands by means of Planted Grasses
}

\section{James Coutts Crawford F.G.S.}

To cite this article: James Coutts Crawford F.G.S. (1883) On Fixing Blowing Sands by means of Planted Grasses, Transactions of the Botanical Society of Edinburgh, 14:1-4, 351-355, DOI: 10.1080/03746608309468421

To link to this article: http://dx.doi.org/10.1080/03746608309468421

册 Published online: 01 Dec 2010.

Submit your article to this journal $₫$

Џ Article views: 2

Q View related articles 5 
barley plant produced about 140 stalks, 130 of which showed the ear out of the sheath. The second had 121 ears; others had fewer, diminishing down to about fifty. The oat plant submitted stood through the winter, and produced about 10,000 returns.

Now, as the tillering process in the barleys was going on during the whole season, some of the ears were not ripe when the plants had to be pulled. But, notwithstanding this, there can be no doubt that, in order to reap the full advantage of seed corn, it should be sown or deposited as near the surface as possible. This would be true of autumn sowing as well as spring sowing, were the former not affected by frost; but a severe winter renders deeper seeding advisable for other reasons than those directly connected with the development of the seed.

\section{On Fixing Blowing Sands by means of Planted Grasses. By James Coutts Crawford, F.G.S.}

(Read 13th April 1882.)

"They manage these things better in France." If a thorough plan for fixing sands is required, we must probably go to France for an example. There large areas in the Landes and elsewhere have been reclaimed by the thorough process of enclosing the sand with brushwood, in squares of thirty yards ( $\mathrm{I}$ think) each way, and planting the spaces thickly with Pinus maritima. Thus an article of some value is raised, the timber of these pines being sawn up for the manufacture of wine cases, and the resin which the trees yield used for covering the corks of the wine bottles.

This mode of reclaiming sandy tracts, however, must necessarily be very expensive, involving a great deal of labour; and where the climate is severe, and the locality exposed to strong winds, as in many parts of Great Britain, might probably not be successful; and it may not be amiss that I should describe certain successful operations undertaken by me in New Zealand, by which I succeeded in fixing several hundred acres of sand situated in a very unfavourable position for the purpose.

I will state what was done:-About the year $1859 \mathrm{I}$ imported $£ 5$ worth of seed of Ammophila arundinacea, 
or common bent grass, and Elymus arenarius, or sea lyme grass, from Messrs Lawson of Edinburgh.

I employed a careful man to sow this seed over a large area of land, burying it sufficiently with a spade. The locality was one very much exposed to both north-west and south-east winds, lying partly between lyall and Evans Bays, at Wellington, and altogether open to Lyall Bay and the southerly winds.

The climate of New Zealand, although sufficiently rainy, is much more elastic and buoyant than that of Great Britain; the ground dries much more rapidly after rain, and therefore there is more facility for the wind causing the sand to drift.

For several years after sowing the seeds I observed no signs of the required plants, but at last $I$ found about half a dozen bunches of them in a small and sheltered glen. I found that upon pulling up one of these bunches I could divide the roots into a number of plants, perhaps from fifty to two hundred. These I planted out, and in the following year had a number of additional plants upon which to operate, and the planting has since gone on steadily increasing until several hundred acres are now secure from risk.

The sand once fixed by the bent, clovers, and other grasses take root, and a fair pasture is established.

These operations took me a long time. They have already gone on for over twenty years, and they are still in progress; but I had to educate myself up to the system, and find out by experience the best plan of operations, and therefore there was much loss of time.

All the manuals on the subject recommend different plans of sowing the sand-fixing grasses. Now I found that sowing was practically of little or no use at all. The seeds germinated, but were almost invariably blown out, and entirely disappeared in the course of a few months. It is advisable to sow a patch in a sheltered place to form a nursery for plants, but it is of little use to sow on open sand.

I next found that it was of little use to plant shallow. The plants were either blown out or were gradually turned over, so that eventually the leaves were buried and the roots were in the air.

At length I found that if the spade was put down as 
far as the foot could press it, and the plants then put in, that they almost invariably succeeded, and this system I have continued with great success. The plants should be put in pretty close, say from one to three feet apart. I found that Maories were much better than white men for this work; they were not so impatient. The white man likes to get over a large quantity of ground without reference to the quality of the work; the Maroi is less inpatient and more careful.

It is advisable to cut off the tops of the plants when planting, and leave only a small part exposed above ground, as exposed leaves are apt to twist round each other, and perhaps destroy the growing shoot.

In New Zealand I would plant during all the cool and moist part of the year, say from March till October. In Great Britain I should think planting could go on all through the autumn, winter, and spring, except when freezing or the land covered with snow.

It is certainly desirable, although not indispensable, that the land which is planted should be enclosed, so as to keep off stock while growing,

My original stock of Elymus entirely disappeared. I afterwards introduced from Christchurch buth Elymus arenarius and $E$. giganteus. The latter is, I think, very valuable for sand-fixing, as it takes a very firm hold on the ground, and therefore is difficult to pull up, and it throws out a great amount of foliage.

The principles which I advocate may be summarised as follows:-

1. Plant instead of sowing.

2. Plant deeply.

If a large area of land is to be operated upon, a regular staff of men should be employed under the direction of an intelligent head man, who ought to give the matter of the proper places in which to commence planting his attentive consideration. The prevailing winds should be studied, and the plunting should always begin on the windward side. By and by, when the plants give much seed, many of them will lodge in hollows which are afterwards covered up by blowing sand, and in this way seeding may be said to answer. 
From time to time, and from year to year, the plan of operation may have to be modified, and the old plantings watched and filled up as required. All this requires a careful man to look after matters.

I am under the impression that although my plants threw up seed stalks yearly, very few of the seeds ripened until the plants attained a considerable age. Now an enormous quantity of seed is annually produced, which helps by vegetating to fill up gaps.

It may be as well to recapitulate the plants used, viz.:Ammophila arundinacea, or common bent (Marram, English; Oyât, French), Elymus arenarius, Elymus giganteus.

The reclamation of sandy tracts must under any circumstances be an expensive operation, and possibly not repaid by a direct return, but it may frequently be desirable or even absolutely necessary to incur this outlay, as adjoining land is always in danger of being overwhelmed while the sand remains in an exposed state.

Note by Editor,-In the Transactions and Proceedings of the New Zealand Institute, 1881, vol. xiv. p. 89, is a paper by W. T. L. Travers, F.L.S., on the Sand Dunes of the West Coast of the District of Wellington, which refers to the successful cultivation by $\mathrm{Mr}$ Coutts Crawford at Miramar Peninsula, and gives the following List of Plants found upon the Sand Dunes of New Zealand:-

\section{Sandinding Plants. \\ Of Primary Value.}

Coprosma acerosa, A. Cunn. Convolvulus soldanella, Linn. Pimelea arenaria, A. Cunn. Leptocarpus simplex, A. Rich. Carex pumila, Thunb.

Hierochloe redolens, Labill.
Spinifex hirsutus, Labill. Arundo conspicua, Forst. Desmoschoenus spiralis. Scedonorus littoralis, Palisot. Gahnia arenaria, Hook. fil.

\section{Of Secondary Value.}

Hymenanthera crassifolia, Hook. fil.

Plagianthus divaricatus, Forst. Haloragis alata, Jacq.

Tetragonia expansa, Murray.

\footnotetext{
Aciphylla squarrosa, Forst. Coprosma Baueriana, Endl. Cyathodes acerosa, Br. Chenopodium glaucum, Linn. var. ambiguum.
} 
Atriplex cincea, Poiret.

Atriplex Billardieri.

Salicornia indica, Willd.

Muhlenbeckia adpressa, Lab.

Muhlenbeckia complexa, Meisn.

Phormium tenax, Forst.

Phormium Colensoi, Hook. fil.

Juncus maritimus, Lam.
Cyperus ustulatus, A. Rich.

Scirpus maritimus, Linn.

Carex virgata, Sol.

Zoysia pungens, Willd.

Dichelachne stipoides, Hook. fil.

Agrostis pilosa, A. Rich.

Glyceria stricta.

Festuca scoparia.

[This enumeration may be useful to those engaged in the reclamation of Sand Dunes in various countries. -ED.] .

On Lichens (1) from Newfoundland, collected by $\mathrm{Mr}$ A. Gray, with a List of the Species ; (2) from New Zealand; (3) from the South of Scotland. By J AMES Stirton, M.D., F.L.S., \&c.

(Read 9th March 1882.)

The following lichens, which I have the pleasure of laying before the Society, were collected at Brigus, Newfoundland, during a two months' trip in the summer of 1878, by $\mathrm{Mr}$ Archibald Gray, Edinburgh. Mr Gray informs me that the lichens which he saw in that country were splendidly developed-the natural features of the country being well adapted for their growth. Some specimens (Umbilicaria) were gathered on bare rocks on the higher grounds near Brigus, at an altitude of about 250 feet; Nephroma arcticum, tolerably common in Newfoundland, was got about 100 feet above the sea near the cliffs at South Head of Brigus; some-as the Cladonioein the rocky woods, to a distance of ten miles inland; others (Usnea, \&c.) on the trunks of fir trees, and (Lecidea) on rocks by the sea. None were gathered at a greater elevation than 400 feet. Mr Gray has also mentioned that icebergs are frequently stranded by the Polar current during winter, along the rough rocky coast of Conception Bay, near where the specimens were collected. The remnant of an iceberg was seen by him aground in the bay as far on in the season as the end of June, while crossing from Portugal Cove to Brigus. Thus the presence of Arctic forms near the sea-level so far south may be accounted for.

1. This small collection of lichens, gathered within two 